\title{
Ravimitest 18. ja 19. sajandi eestikeelses kalendrikirjanduses ${ }^{1}$
}

Stella Martsoo

Igal asjal on oma aeg. Soolapuhujate, pusijate ja sõnadega aitajate aeg on möödas, meil on praegu arstirohtude aeg

(H. Koppel. Arstirohtudest ja nende tarvitamisest. SL 1898: 23).

Teesid: Kuidas sattusid rahvameditsiini ravimite sekka sellised "apteegirohud" nagu aedvaagijuur, juudasitt, salpeeter jt? Üheks allikaks olid kohalikud mõisnikud ja nende prouad, kes propageerisid nii Saksamaal ilmunud kirjanduse kui ka isikliku kogemuse põhjal omandatud ravimialaseid teadmisi. Kuid arvestavaks allikaks võis olla ka juba 18. sajandi lõpul ilmuma hakanud eestikeelne kalendrikirjandus ja 19. sajandi lõpupoole sagenenud populaarse meditsiinikirjanduse väljaandmine, kus tutvustati tolleaegseid värskemaid meditsiiniteadmisi. Antud kirjutises leiavad käsitlust nimetatud ajavahemiku kalendrikirjanduse meditsiinialastes tekstides avaldatud ravimi- ja ravimisalased nõuanded. Kuna nüüdisaegses tähenduses ei olnud toona enamikul juhtudel ravimitega tegemist, võtkem terminit ravim käesolevas kirjutises tavapärasest laiemas mõttes.

Märksõnad: arstirohud, eestikeelne kalendrikirjandus, ravimine, 18. ja 19. sajand

\section{Kalendrikirjandus}

Esimesed Eestis trükitud kalendrid olid saksakeelsed ja nende ilmumise algus ulatub 17. sajandisse, mil anti välja Tallinna esimene kalendrisari. Selle koostajaks oli Gebhard Himsel (1603-1676), kes mitmekülgse inimesena oli muuhulgas ka Tallinna linnaarst ja Raeapteegi juhataja. Esimene kalender ilmus oletatavasti 1635. aastal. Kalendrisari ilmus ühtekokku 41 aastat, kuni G. Himseli elu lõpuni. Järgmise saksakeelse kalendrisarja (1718) 
väljaandjaks oli Johann Köler, kes peagi lisas sellele ka eestikeelse kalendrisarja, mille algusaastat täpselt ei teata. Oletuslikult on see siiski paika pandud tänu kalendris osade kaupa avaldatud vaimulikele lugudele. Arvestades peatükkide pikkusi säilinud eksemplarides ja ka seda, et lugude ilmumine algas esimesest kalendrinumbrist, nägi esimene eestikeelne kalendrisari ilmavalgust ilmselt 1720. aastal. Vanim teadaolev kalender pärineb aastast 1731, see on aga tänaseks ajalookeerises kaduma läinud. Varaseim säilinud kalender anti välja aastal 1732 . Võrdluseks võib mainida, et esimene lätikeelne kalender ilmus 1750. aastatel, leedukeelne aga alles 1846. aastal (Annus 2000b: 13).

Kalender ehk tähtraamat oli üheks esimeseks ilmalikuks raamatuks talurahva lugemisvaras. Odava perioodiliselt ilmuva tarbetrükisena saavutas see rahva seas kiirelt populaarsuse. Kalendri väljaandjad soovisid eelkõige suurt läbimüüki, mistõttu arvestati hoolsalt lugeja huvide ja ootustega. Kalendrit võiks pidada koguni ilmalikuks katekismuseks, mis jagas talurahvale igapäevaeluks kasulikke nõuandeid, õpetusi ja uudiseid laiast maailmast. Kodust eemal toimuvast saadi enne ajalehtede väljaandmise algust teada üksnes kõrtsis, teolt tulles, pühade ajal kirikus käies ja laatadel. Seega oli kalendril talupoja maailma avardamisel ja teabe hankimisel oluline osa. Et kalendrid olid suunatud maarahvale lugemiseks, ilmusid nad esialgu hilissügisel - ajal, mil talutööd tehtud. 19. sajandi teisel poolel oli kalendrite ilmumine nii massiline, et tihedas konkurentsis hakati neid avaldama juba jaanipäeva paiku (Noodla 1986: 14).

Lugemisvara, sh kalendreid, hangiti linnas trükkalilt, raamatuköitjalt, laadalt, kõrtsist, koolmeistrilt või pastorilt, ka rändkaupmeestelt. Lõunaeestikeelseid kalendreid jm odavamat lugemisvara hakkas 19. sajandi esimesel poolel levitama ka Õpetatud Eesti Selts (ÕES). Tänu seltsi organiseerimisele õnnestus maarahval kirjavara ostma hakata ka talurahvapoodidest (Talve 2004: 342). Kalendril oli majapidamises oma kindel koht - see rippus seinal nööri otsas (Vinkel 1965: 432). Esimesel aastal kasutati seda teatmeteosena, edaspidi juturaamatuna kuni selle kulumiseni (Annus 2000b: 13).

Kalendrid koosnesid kalendaariumist ja kalendrilisast, mida nimetati ka kalendrisabaks. Algselt asus kalendrilisa kalendaariumi sees lehekülgede servas. Alates 1779. aastast, tõenäoliselt kalendrilisa mahu suurenemise tõttu, pandi see kalendaariumi lõppu pärast päikese- ja kuuvarjutusi ning laadateateid. Terve aasta kohta toodi julgelt ära ennustused ilma, viljasaagi, sõja ja rahu, tervise ja haiguste kohta. Lisaks avaldati iga päeva kohta päikesetõusu ja -loojangu kellaajad, ehkki maarahval kella enamasti polnudki (Vinkel 1965: 192-193). Kalendaariumist ei puudunud ka märgid, mis 
tähistasid soodsaid päevi, millal rohtu võtta, aadrit lasta, last võõrutada, puid raiuda jne.

19. sajandi alguseks oli kalender jõudnud oma levikult juba väga laia lugejaskonnani. Seda tõendavad suured tiraažid ja uute kalendrisarjade loomine. Lugejaskonna suurenemisele aitasid omalt poolt kaasa sajandi algul intensiivistunud koolielu, külakoolide raamatukogude asutamine, samuti majandusliku olukorra mõningane paranemine ja nõudlus praktilisemate teadmiste järele. Kalendritel on ka suur tähtsus raamatute populariseerimisel - 19. sajandi algusest alates on neis avaldatud ilmunud raamatute nimekirju ja soovitusi nende ostmiseks. Nad olid esimeseks raamatureklaami avaldajaks ning ühtlasi ka raamatubibliograafia tekke aluseks (Kangur 2004: 90).

19. sajandi teisel poolel hakkas kalendrite tähtsus kahanema ajalehtede, ilukirjanduse, õpikute, aime- jm raamatute sageneva ilmumise tõttu. Samas olid kalendrid endiselt väga populaarsed, neid andsid välja kõik suuremad trükikojad. Sajandi keskel oli suuremate kalendrite tiraaž 5000-6000 (Vinkel 1965: 432), mis oli selle aja kohta väga suur - ainuüksi raamatu 1000 eksemplari läbimüük 10 aastaga näitas sel ajal head minekut (Loosme 1966: 73).

Kalendrilisa oli 18. sajandi populaarseim kirjavara, mis oli algselt vaid vaimuliku sisuga, jutustades lugusid Vanast Testamendist. 18. sajandi teine pool tõi kalendrisse juba ilmalikku laadi kirjandust. Kalendrilisasse ilmusid rahva silmaringi laiendavad ja praktilist laadi teemad, nagu tervishoid, põllumajandus, majapidamine, kaugete maade kultuur, geograafia, ajalugu, loodus jm. Tervishoid ja esmaabi on kalendreis üks sagedasemaid teemasid (Annus 1975: 179).

19. sajandi teisel poolel paranes kalendrikirjanduse tase oluliselt tänu silmapaistvatele ja haritud kirjameestele, nagu Friedrich Reinhold Kreutzwald, Johann Voldemar Jannsen, Friedrich Robert Faehlmann jt. Kalendrilisa autorist sõltus oluliselt kalendri edu. Laakmanni trükikoja avaldatud Maarahva Kasuline Kalender oli rahva hulgas üks populaarsemaid. Selle menu võti peitus kindlasti Fr. R. Kreutzwaldi loomingu avaldamises. 1874. aasta kalender oli tänu Fr. R. Kreutzwaldi juttudele niivõrd populaarne, et sellest anti välja koguni kuus trükki ehk ühtekokku 18400 eksemplari (Talve 2004: 457). Lõbusate juttude kõrval pööras Fr. R. Kreutzwald tähelepanu ka rahva kehva elujärje parandamisele ning ärgitas neid aktiivsemalt tegutsema. Paljude kasulike õpetuste seas oli ka juhiseid ikaldusaastail toimetulekuks (nt samblaleiva tegemiseks jpm) ning põllumajanduse tõhustamiseks (Nirk 1968: 176). Fr. R. Kreutzwald, Dietrich Heinrich Jürgenson, Friedrich Robert Faehlmann ja teised õpetatud arstid, kuuludes Õpetatud Eesti 
Seltsi, on avaldanud ÕESi kalendrites mitmeid meditsiinilisi, peamiselt nakkushaigusi käsitlevaid kirjutisi.

\section{Metoodika}

Käesoleva artikli aluseks on 18. ja 19. sajandil ilmunud eestikeelsed kalendrid, mis sisaldavad meditsiinialaseid kirjutisi inimese ravimise kohta. Siinkohal tuleb tõdeda, et inimese ravimise ja ravimitega võrreldes on kalendrites rohkem veterinaarmeditsiinialaseid tekste (Alatalu 1992). Kuni aastani 1850 ilmunud kalendrite valikul on tuginetud kalendrilisa lugude pealkirju kajastavale bibliograafiale Eesti raamat 1525-1850 (Annus 2000a). Aastast 1851 ilmunud kalendrilisade kohta annab bibliograafia (kaheköiteline Eestikeelne raamat 1851-1900 (Annus 1995a, 1995b) teavet vaid kirjandus-

Tabel 1. Ravimialast teavet sisaldavad kalendrid 18.ja 19. sajandil (aastaarv näitab aastat, mille puhuks kalender välja anti, sulgudes on sama aasta kohta ilmunud kalendrite arv)

\begin{tabular}{l|c|l} 
Periood & Kalender & Aastakäigud \\
\hline $1790-1800$ & 3 & $1792,1793,1799$ \\
\hline $1801-1810$ & 3 & $1804,1805,1806$ \\
\hline $1811-1820$ & - & - \\
\hline $1821-1830$ & 1 & 1824 \\
\hline $1831-1840$ & 3 & $1831,1835,1840$ \\
\hline $1841-1850$ & 1 & 1841 \\
\hline $1851-1860$ & 7 & $1851,1853,1856,1857(2), 1858,1859$ \\
\hline $1861-1870$ & 3 & $1864(2), 1866$ \\
\hline $1871-1880$ & 11 & $1871(2), 1875,1877,1879(2), 1880(6)$ \\
\hline $1881-1890$ & 12 & $\begin{array}{l}1881(2), 1883,1884,1885,1886(2), 1887(2), 1889, \\
1890(2)\end{array}$ \\
\hline $1891-1900$ & 21 & $\begin{array}{l}1891(2), 1892(2), 1893(5), 1894(3), 1896(3), \\
1898(3), 1899(2), 1900\end{array}$ \\
\hline
\end{tabular}


like lugude ulatuses. Seetõttu on hilisemad kalendrid (1851-1900) valitud Riin Alatalu koostatud diplomitöö (1992) meditsiinilise bibliograafia alusel. Kasutatud kalendreid on kokku 65. Nende aastakäigud on toodud tabelis 1.

\section{Meditsiin kalendrites}

Meditsiinilise teksti osa kogu kalendrist on raske hinnata. Ilmunud kirjutiste pikkused on väga erinevad, sõltudes kalendri formaadist, rubriigist, autorist, teemast ja kalendrilisa mahust. 1792. aasta Eesti-Ma Rahva Kalendris on näiteks 22-leheküljeline kirjutis, samas oli kalender siis formaadilt kõigest väikese taskumärkmiku suurune. Seega ei ole lehekülgede arv meditsiinilise osa mahu hindamiseks sobiv. Küll aga on märgatav üks üldine tendents meditsiinilise kirjutise pikkuses - esimestes ravitsemist puudutavates kalendrites moodustas see kogu kalendrilisa mahu, hiljem muutus aga üheks jutuks paljude seas. 19. sajandi lõpupoole kahanesid õpetused aga lõikudeks nõuannete ja õpetuste rubriigis.

Kalendris avaldatu oli kas tõlgitud, refereeritud, kalendri koostaja poolt mitmest allikast kokku pandud või kalendrilisa tarvis kirjutatud. Tõlgitud või mitmest teosest kokku kirjutatud tekstide allikaist kalender enamasti vaikib. Leidub siiski tekste, mille puhul on allikas tuvastatud, kui see on näiteks "näpatud" mõnest tolleaegsest teosest. Üheks selliseks teoseks on Peter Ernst Wilde Arsti raamat nende juhhatamisseks kes tahtwad többed ärraarvada ning parrandada (1771), kust pärinev materjal on avaldatud 1792. aasta Eesti-Ma Rahva Kalendris. See oli ühtlasi ka esimene kalender, kus avaldati meditsiinialaseid nõuandeid. P. E. Wilde raamatust on pärit peatükid sõrmesööbija (sõrme vigastusest tekkinud luu- ja luuüdipõletik) raviks ja külmunud inimese abistamiseks. Lisaks laenati kalendrisse materjali ka Friedrich Gustav Arveliuse Ramma Josepi Hädda- ja Abbi-ramatust (1790), millest 1793. aasta Eesti-Ma Rahva Kalendris avaldati õpetusi elustamiseks varjusurma, külmumise ja uppumise korral ning 1799. aastal artikkel äädikast ja selle raviomadustest.

Uurimust raskendab asjaolu, et kalendrilisa autorid ja lugude allikad on peaaegu kõik anonüümsed - autori ja allika avaldamist ei peetud tollal oluliseks. Ühelt poolt ei osanud lugeja selle vastu veel huvi tunda, teiselt poolt võis autor karta oma väljaütlemiste pärast kriitikatule alla sattuda (Annus 2000b: 55). Vaid mõnel artiklil on nimetähed all, mis lubab oletada, kes on autor. Kalendritekstide autorsus on keerukas omaette uurimisteema. Tekstide lõpul avaldatud initsiaalide alusel on mõningate lugude autorid siiski teada: F. K. all kirjutas Fr. R. Kreutzwald 1851. aasta Ma-rahva Kalendris 
kõhutõvest, F. F. taga peitus Fr. R. Faehlmann, avaldades 1841. aasta Tartoja Wõrro-ma rahwa Kalendris loo sarlakitest ning D. J. all kirjutas sama kalendri 1840. aasta numbris sügelistest Dietrich Heinrich Jürgenson.

Kuna tähtis oli kalendris avaldatu atraktiivsus ja loetavus, võisid nii mõnelgi juhul artikli kirjutada ka vastavas valdkonnas asjatundmatud inimesed, kes suutsid materjali huvitavamalt ja rahvapärasemalt lugejani viia, kui seda teinuks erialainimesed rahvale mõistetamatus erialakeeles. Tõlgitud tekstide puhul aga jääb tõlkija kompetentsus sageli selgusetuks. Tal võis tekkida ühelt poolt vigu algteksti mõistmises, teiselt poolt aga selle lugejale sobivasse keelde "tõlkimise" täpsuses, sest eestikeelne meditsiinisõnavara oli tollal alles kujunemisjärgus, mistõttu tuli lahendada maarahvale tekstide arusaadavaks kirjutamise probleem.

Kalender pole oma kirjatükkides sugugi alati arvestanud maarahva hetkeseisuga ja on mõnelgi juhul ajast etteruttav. Nii soovitab juba 1792. aasta Eesti-Ma Rahva Kalender ravimeid apteeki ostma minna, ehkki esimene püsivalt tegutsev maa-apteek avati Eestis alles 1861. aastal ning laiem maaapteekide võrgustik kujunes 19. sajandi lõpupoolel. Muidugi polnud apteek ainus koht rohtude hankimiseks - ravimeid saadi ka rändkaupmeestelt. Samas kalendris soovitatakse arsti poole pöörduda, kui sõrmesööbija juba luu kallal on, et tohter kahjustunud luu välja tõmbaks. 18. sajandi lõpul oli arste aga sedavõrd vähe, et vaevalt oli talurahval võimalik tohtri juurde minna. 1806. aasta Eesti-Ma-Rahva Kalender aga annab nõu süüa keedetud kartulit, kui midagi teravat on kurku kinni jäänud, 1831. aasta kalender jagab õpetusi kasutada toorest kartulit kuuma vedelikuga saadud põletuse raviks. Samas polnud 19. sajandi esimesel poolel kartul veel laialt levinud põllukultuur. Mõisapõllul ja mõne talupoja aiaski kasvatati kartulit siiski juba 19. sajandi algul (Viires 1992: 371).

1857. aasta Eesti rahva Kalender soovitab minna koduapteegi tarvis korjama taimi, mis Eestis looduslikult ei kasva (nt ümaralehine kassinaeris, altee, ürt-allikkerss). Võimalik küll, et neid kasvatati sel ajal mõisaaedades, kust taimed levisid ka talupoja koduaeda. Samas artiklis on hulgaliselt tõlke- või trükivigu taimede ladinakeelsetes nimedes ja nende eestikeelsete taimenimede vastavuses. Näidetena olgu toodud so kanna arg ehk kailud ehk so-kikkas, mille ladinakeelseks vasteks on Lepidium ruderale - rahvapärased nimetused viitavad sookailule, ladinakeelne nimetus aga haisvale kressile. Taime kasvukoha kirjeldusest selgub, et tegemist on haisva kressiga. Samuti on eksitav raud rohhi ehk verre hain (Tanacetum vulgare), mida soovitatakse pruukida koirohuga samadel näidustustel nagu solikatte vastu ja sonede kinnivötmistes, mis terve ihhu nödrussest ehk solikatte seadmisses koggumissest sünnivad, mille alusel on raske öelda, kas tegemist on 
raudrohu (Achillea millefolium) või soolikarohuga (Tanacetum vulgare). Muu hulgas mainitakse, et ubaleht kasvab heinamaadel ja mujal kuivades kasvukohtades, mis taas ei kinnita selgelt, mis taimest on jutt. Leidub ka vigaseid või tänapäevasest kirjapildist erinevaid ladinakeelseid nimetusi, nagu Sumbucus nigra (vrd Sambucus nigra), Filia europea (vrd Tilia spp.), Mengarithas europea (vrd Menyanthes spp), Althaca officinalis (vrd Althaea officinalis), Rechoma hederacea (vrd Glechoma hederacea), Arbutus Uvaursi (vrd Arctostaphylos uva-ursi). Segasevõitu artikli päritolu on teadmata, tõenäoliselt on see tõlgitud mõnest käsiraamatust, kuid asjatundmatult ja vigaselt. Teatud mõttes võib siinkohal tuua paralleele tänapäeva populaarse meditsiinikirjanduse ja internetiportaalidega, kus meditsiinist kirjutatakse palju, samas ei saa selgust, kust levitatavad tõekspidamised pärit on. Nende tõesuses ei oska tavainimene enamasti kahelda ega nende suhtes kriitiline olla. Nii oli ilmselt ka 19. sajandi kalendrikirjandusega - seda, millest kirjutati, võeti tõe pähe ja "söödi" aplalt sisse.

Kalendrite autoriteetset taset võib tänapäeval siiski vaid oletada, sest meile jääb teadmata, mida ja kui palju talupoeg kalendrist endale teadmiseks võttis, mida kõrvale jättis. Teame vaid, et kalendritest peeti enamasti lugu. Säilinud eksemplaride hulgas on selliseid, mille tiitellehele on kirjutatud mitu sama perekonnanime kandvat nime, mis tõenäoliselt tähendab kalendri pärandamist järgnevale põlvkonnale. Kirjandusmuuseumi arhiivis säilitatakse aga kokkuköidetud kalendrilisasid (Loosme 1966: 77), mis annab tunnistust kalendritrükise tähtsusest ja olulisusest. Ühe kalendri siseküljelt võib lugeda pühendust:

[---] ma-konna Piiskoppi Herra kässo järrele, saab se kalender [---] kingitud Laimjalla kerriko [---], selle kollipoisi Sarewalla ja külla tallomehhe poja Aleksandrile Rand temma igga kortse kolisekäimisse ja olega öppemisse ning omma hea üllespiddamisse eest Sakla kolis. Pasto ku 3mal päwal 1862 aastal Sakla moisas,

millele on alla kirjutanud preester ja kaks köstrit. Siinkohal võib mainida, et tegemist oli 1857. aasta kalendriga - seega polnud kingituseks kõige uuem trükis.

Leidub õpetusi, mille puhul on mainitud, kes seda õpetas, soovitas või seeläbi tervenenud on, mis annab loole juurde jõudu ja suurendab selle usaldusväärsust. Selline "tõestussüsteem” ei ole tänapäevalgi kuhugi kadunud, kuigi selle peale võiks õlgu kehitades küsida: "Ja mis siis?" Kuid siinkohal üks tekst 1880. aasta Kasulisest Talurahva Kalendrist, kus jagati nõuandeid ravimaks marutaudis koera hammustust: 
Vana 82. aastane metsasaks Gastel ütles: "Ma ei taha oma rohu saladust hullust koerast kistud haavale mitte ühes hauda võtta, vaid selle avaldusega viimse hia tiu ilmale teha: Võta sooja viina äädikat ja leiget vett, pese sellega haav hiaste puhtaks ja kuivata siis ära. Selle järele kalla mõni tilk soolahapatust (Acidum muriaticum), mis apteegist saada, haavasse ja ole kartuseta; hulluks Sa ei lähä.”

Ka tohtri nimel tuleb kalendreis soovitusi ette:

Koolera tõvve vastu kiidab üks Tallinna arst kõigeparama olevad: Õeru seljarodu, rindu ja kõhtu lendva salviga (flüchtige Salbe), mis igast apteekist saada on ja haiguse ajal igas majas peaks valmis hoitama (KTRK 1879).

Sellised umbisikulised soovitused hakkasid kalendreisse imbuma 19. sajandi teisel poolel, mil meditsiinilised õpetused ilmusid majapidamisnõuannetega ühes rubriigis.

Esmakordselt soovitas kalender apteeki rohtu ostma minna juba esimeses meditsiinitemaatikat sisaldavas kalendris 1792. aastal. Selles leidus õpetusi haavade ravitsemiseks, Emmaga vigga puhul, paistetuste ja paisete, sõrmesööbija ja külmumise kohta. Haavade paranemisel tekkida võiva liigliha vastu soovitas kalender osta Apteki peält üks kivvi mis seäl Azstein nimmetakse, sedda tehhakse kallist Tuhhast (Pott-asche) [potas ehk kaaliumkarbonaat] ning Lubjast. Vanade paisete puhul soovitati käituda järgnevalt:

Osta selle tarvis Apteki päält: Penikesseks toukatud Kalmei (Galmey Silberglätte) [kalmei ehk kalmeikivi] kolm Sörm-kübbara täis PleiWeiss [tinavalge e. tinakarbonaat], nelli Sörm-kübbara täis ööro sedda hästi kokko, valla haval pissut Poom-Ölli [puuõli] jure, et ta saab Puddro-visil, ja panne sedda peäle (EMRK 1791).

Kolmandaks anti soovitus osta apteegist rohelist seepi, et sellest külmunud liikmete ravitsemiseks kodusel teel koos piimaga salvi keeta. Lisaks on kalendris mainitud mitmeid teisigi apteegiravimeid, nagu loorberit, väävlit, juudasitta (juudavaik ehk asaföötida), tärpentini, tärpentiniõli, mürri, kübaramusta (raudvitriol), maarjajääd, kustutamata lupja, krinspanit (aluseline vaskatsetaat), aedvaagijuurt.

Terviseteemat on puudutatud ka varasemates kalendrites. Teadaolevalt hakkas 1731. aastast kalendrilisas ilmuma jutuke "Tervissest ning haigussest", milles aga tolleaegse vaimuliku kalendrisisu tõttu soovitati haiguste korral vaid jumalale loota. Alles aastaid hiljem (1749) ilmus kalendris lugu, milles rõhutati haigele rohu hankimise ja tema õige hooldamise tähtsust. 
Kuidas sügelistest kolme päevaga lahti saada, kirjutas D. H. Jürgenson (TVMRK 1839). Mainimisväärne on antud lugu selle poolest, et arstimise juures on kalendris esmakordselt ära toodud ladinakeelsed retseptid: sügelistevastane pulber sissevõtmiseks ja salv pealemäärimiseks. Pulbrisegu koostisse kuuluvad kadaka- ja loorberimarjapulber, salvis on lisakomponendiks väävel. Sealjuures on mainitud, et need rohud aptegi peält oddava hinna eest on sada. Kui odav või kallis ravim tegelikult oli, jääb teadmata. Ma-rahwa Koddo-Arstist (Jannau 1857) leiab mõningate majapidamises soovituslike arstirohtude hinnad, paraku pole lisatud kaaluühikuid, mistõttu jääb ravimi kogus teadmata. Kõrgeima hinnaga (10 kopikat) on kamper, kampripiiritus, köharohi, krampvi tropid, oksendamise juur, Ovmanni liikvor, pansvligi pulver, rinnarohi, sinep ja tärpentiniõli. 5 kopika eest oli saada glaubrisoola, kübaramusta, puuõli, salpeetrit ja salmiaaki. Odavaimad olid pipar ja väävel, makstes vaid 3 kopikat (MRK 1856: 120).

\section{Ravimid kalendrites}

Kalendritekstides ei tule selgelt esile rahvameditsiini põhimõtteid, nagu ravida sarnast sarnasega, ravimi päritolu olgu sealt, kust haiguski ning et ravim oleks kangem kui haigus (Manninen 1925). Varjatult võib aga seoseid leida, kas või raudnõgeste kasutamine põletuse puhul (UTT 1897: 95). Irratsionaalsetest ravivõtetest kalender üldjuhul hoidub. Üksikutel juhtudel on selliste sugemetega ravimeid mainitud roosi puhul. 1859. aasta kalender suhtub roosi rahvapärastesse ravimitesse ükskõikselt:

Tallorahvas kattavad sedda kohta, kus roos on, punnase kallevi ehk sinnisse suhkru pabberiga kinni, kelle alla on kriidi pulber rapputud. Need asjad ei olle mitte kahjulikkud, agga siiski ei too ka ennam kassu, kui needki, mis meie jo ülleval näitasime (ERK 1858: 39).

Paraku toovad hilisemad kalendrid roosi raviks eelnevad talurahva "kahjutud ja toimetud" tarkused teiste asjalike õpetuste seas ära vägagi loomupärastena:

Roosi kautatakse selle läbi, et ta pääle siniseks värvitud linast riiet pannakse ja sääl mõne aja hoitakse. Sedasama tehakse ka paberiga, mis enne pleihveedriga ehk pliiatsiga hästi täis piab kritseldama (IK 1879: 78).

Roosi vastu: siniseks värvitud linane riie ehk paks sinine paber pliiatsi mustaga üle tehtud (UTT 1897: 97). 
Sinine paber on rahvapärimuse alusel osutunud roosi puhul kõige levinumaks ravivahendiks. Üldlevinud komme oli ka eespool näites toodud kriidi (või jahu) puistamine sinisele paberile (Veidemann 1985: 138).

Karl Ernst von Baer mainib oma 1814. aastal valminud doktoritöös Eestlaste endeemilistest haigustest eestlaste seas sagedamini tarvitatavate arstirohtudena piiritust, äädikat, väävelhapet, püssirohtu, elavhõbedat, juudasitta, tärpentiniõli ja väävlit (Baer 1976: 117). Tähtraamatuis puuduvaid neist ainetest elavhõbe ja püssirohi, mida, tõsi küll, on mainitud, kuid mitte soovitatud inimesele manustada.

Kalendrites esinevatest ravimitest ja ravivõtetest annab ülevaate joonis 1, mis kajastab vastavalt näidustuste hulga alusel nende osa kalendriõpetustes. Ravivõtete all on silmas peetud kaanide ja kuppude panemist, harjamist ja hõõrumist, sooja-külma kasutamist jm. Kõige suurema osa võtavad enda alla apteegirohud. Kui võrrelda kalendriõpetustest saadud tulemusi rahvameditsiinilise pärimustiku põhjal koostatud uurimusega (Raal \& Pilve \& Pilve 1990: 72-76), mis hõlmas 19. sajandi lõppu ja 20. sajandi esimest poolt, on erinevused näha eelkõige taimsete ravimite puhul - kui rahvameditsiinis moodustab see $40-90 \%$ ravimeetoditest, siis kalendriõpetustes üksnes viiendiku.

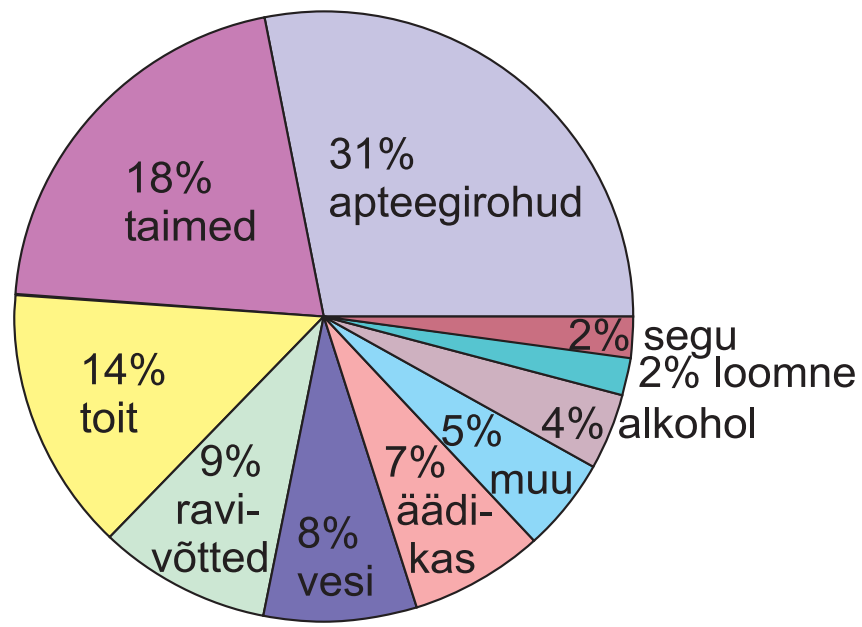

Joonis 1. Ravimite ja ravivõtete osa kalendriõpetustes.

Ravimite kasutusviise on kalendreis väga mitmesuguseid. Enamasti on ravim mõeldud sissevõtmiseks või pealemäärimiseks. Kõne alla tulevad veel auru sissehingamine, klistiiri tegemine, kompressid ja mähised, loputused, ülevalamised, hõorumised, keha kinnikatmine. Õpetusi jagub ravivahendite 
kasutamiseks nii pähe, silma, kõrva, kõrva taha, otsmikule, meelekohtadele, ninna, igemetele, keele peale, kaelale, kaenla alla, rinnale, rinna alla, südame kohale, kõhule, jäsemetele, küünte alla, reite vahele, säärtele, varvaste vahele kui ka talla alla.

Klistiir, nagu ka lahtistite kasutamine, olid 19. sajandil levinud ravivõtted. Populaarse ravivõttena on klistiiri mainitud ka kalendriõpetustes. Seda soovitati kasutada peamiselt esmaabijuhistes pikselöögi tabamuse (EMRK 1804; EMRK 1876: 51), uppumise (EMRK 1803; EMRK 1830), vingumürgistuse (EMRK 1830), mürgistuse (EMRK 1805; EMRK 1830; EMRK 1876: 56), liigjoomise (EMRK 1804; EMRK 1830), külmumise (EMRK 1830; ERK 1864: 45-46) korral ning kukkunud või hoobi pähe saanud (EMRK 1804, EMRK 1830) üles poodud või kägistatud (EMRK 1803; EMRK 1830) inimese abistamiseks. Klistiiri tegemiseks õpetatakse lisaks veele kasutama nii äädika-, viina-, piima- kui ka soolvett. Klistiiri taimedega on soovitatud vaid korra kummelitõmmist kõhugaaside ja -valu korral (ERK 1856: 44). Viina liigjoomisest nõrkenud inimese abistamiseks antakse juhiseid hapuks läinud piimaga (pimavessi) klistiiri tegemiseks (EMRK 1804). Taime- ja seenemürgistuse puhul jagatakse soovitusi teha klistiiri kange kohvega (ERMK 1876: 56), kõhu ummistuse korral aga sooja seebiveega (RTR 1886: 62). Kui me tänapäeval mõistame klistiiri all (ravi)vedeliku juhtimist pärasoole kaudu organismi, siis kalendrites mainitakse muu hulgas ka suitsuga klistiiri tegemist. Selleks soovitati kasutada tubakasuitsu, millest siinkohal ka üks näide uppunu elustamiseks:

Seäl jures on ka hea, kui teie püate selle innimessele tubbaka suitso taggant sisse aidata: ja se voib sel visil sündida: voidke ühhe pibovarre otsa ölli-ehk rasvaga, ja pistke sedda ühe tolli ossa takia pärrasole sisse, vähhe ristlu pole siis vottab üks mees teisest pibust jua, vottab suud, ni paljo kui ta ial voib; täis suitso, ja puhhub sedda keigest väest pibovarre läbbi selle innimesse ihho sisse (EMRK 1792).

Tubakasuitsu klistiiri on veel mainitud 19. sajandi teisel poolelgi, lisaks uppunu elustamisele ka pikselöögist tabatu abistamiseks (ERMK 1876: 51-52).

Silma sisse soovitatakse silmapõletiku korral tilgutada kasepungaviina (K 1892: 64). Siinkohal ei saa jätta lisamata, et viina silma tilgutamist ei tahaks soovitada isegi oma vaenlasele. Oliivõli soovitatakse aga silma tilgutada juhul, kui puru on silmas (K 1892: 62). Leidub ka õpetus tubakasuitsu puhumisest silma, mida soovitatakse teiste abiõude seas ära proovida uppunu elustamisel (EMRK 1792).

Kõrva sisse manustamine tuleb eelkõige kõne alla hambavalu puhul. Sinna soovitatakse sel puhul panna vatitropiga rummi (IK 1880: 89), kummeli- 
tinktuuri, Hoffmanni palsamit (Mixtura oleosa balsamicum) ja prantsuse viinapiiritust (ERKK 1886: 51) või ka lihtsalt kummeliõisi (PMK 1895: 110). Kõrvavalust lahtisaamiseks antakse nõu tükk toorest sibulat kõrva torgata (UTT 1897: 94). Ära on mainitud, et vatiga tuleb ravivahendit panna sellesse kõrva, kus pool haige hammas valu teeb (IK 1889: 89), samaaegselt tuleb teise kõrva pista puhas vatitropp (ERKK 1886: 51). Tuleb märkida, et praegusaja arusaama kohaselt ravimeid reeglina ei manustata kõrva: toimeained sealt ei imendu ning tekkida võib hoopis põletikukolle. Erandiks on kõrvahaiguste ravimine paikselt.

Nina kaudu õpetatakse ravitsema ninaverejooksu puhul, kui ninna tuleb panna äädikaga niisutatud tropp (IK 1879: 77; OK 1893: 22; KTRK 1893: 57; UTT 1897: 96). Nohu korral aga soovitatakse kasutada nina määrimiseks sooja kakaovõid või boorvaseliini. Hambavalu puhul on antud soovitus tõmmata ninna lahjendatud Kölni vett (IK 1880: 89). Viimasel juhul tuleb arvestada põrguliku valuga hellal limaskestal, mis aga tähelepanu hambavalult mõneks ajaks kindlasti kõrvale juhib.

Omapärane manustamisviis on ravimi kasutamine põlve ja kaenla alla, mida soovitab 1857. aasta Eesti rahva Kalender värske taime - haisva kressi (Lepidium ruderale L.) - võimaliku kasutusviisina vahhetava külma többe puhul (ERK 1856: 42). Kaenla alla kuumade tuha- või liivakottide asetamine tuleb kõne alla uppunu elustamise puhul (UTT 1897: 92). Liighigistamise korral jagatakse nõuandeid tolmutada kaenlaaluseid talgi-tärklise-salitsüülhappepulbri või glütseriin-mandlikliidega (ERKK 1886: 54), aga ka pesta seebipiiritusega (UTT 1897: 100).

Kordagi pole kalendreis juttu ravimi panemist keele alla - küllap oli see tollal veel tundmatu manustamisviis. Küll leidub aga soovitus keelele manustamiseks - last, mis ilmale tulles nago surnud on, tuleb "ellu aidata" soolaterasid tema keele peale pannes (EMRK 1804). Kui keel on ära kõrvetatud, soovitatakse sellele jahu raputada (PMK 1895: 110).

\section{Apteegirohud}

Apteegirohud moodustavad kõikide ravimite hulgast ligikaudu kolmandi$\mathrm{ku}$. Levinumad apteegirohud on reastatud joonisel 2.

Selgelt eristuvad ravimeist karboolhape, puuõli ja nuuskpiiritus (salmiaagipiiritus). Väga suur näidustuste hulk esineb õli puhul. Enamasti soovitatakse puuõli (oleum Olivarum commune; Wallner 1929), vähem oliivõli (oleum Olivarum provinciale; Wallner 1929). Mõnel juhul on õli täpsemalt määratlemata jäänud. Kui arvestada õli näidustused puuõli juurde, oleks viimane ülekaalukalt levinuimaks ravimiks apteegirohtude seas. 


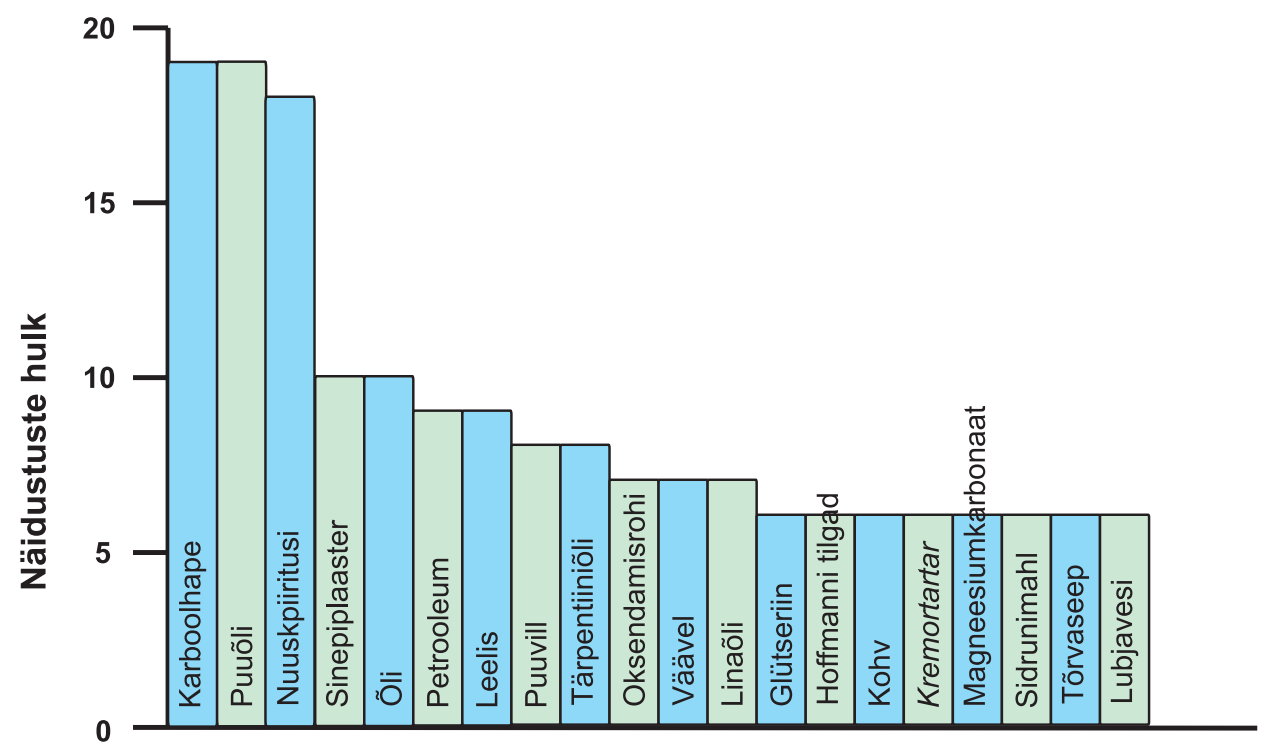

Joonis 2. Apteegirohtude nimetamise sagedus kalendriõpetustes.

Karboolhape ilmub kalendriveergudele alles 1893. aastal (OK 1893). Meditsiinis võttis karboolhape kasutusele inglise kirurg Joseph Lister 19. sajandi teisel poolel. Karboolhape oli oluline uuendus meditsiiniajaloos, pannes aluse antiseptikale. Kahjulikkudest ollustest puhastamiseks soovitati kalendris karboolhapet kasutada nii naha, pesu, riiete, sängi, põrandate, anumate kui ka toa pesemisel (OK 1893: 22). Sellele lisaks õpetati karboolhappelahust kasutama ka hambavalu (OK 1893: 20; UTT 1897: 94), halva hingeõhu (OK 1893: 23; UTT 1897: 97), lahtiste juuste (OK 1893: 20; UTT 1897: 96), liighigistavate jalgade (OK 1893: 20; UTT 1897: 96), sammaspooliku (OK 1893: 23; UTT 1897: 97), lõhenenud käte (OK 1893: 21), ärapigistatud liikmete (OK 1893: 21-22), nohu (OK 1893: 22), paise või kasuja (OK 1893: 22), välise verejooksu (OK 1893: 24) ja haava puhul (UTT 1897: 99).

Sinepiplaastrit mainitakse esmakordselt 1841. aasta kalendris (TVMRK 1840: 50). Seal soovitati panna plaaster sarlakihaige paistetanud kaelale. Nüüdisaegse arusaama kohaselt ei tohi põletikukoldeid soojendada, eriti veel lümfisõlmedes asuvaid koldeid. Teiselt poolt aitab sinepiplaaster kudede ainevahetusele kaasa küll. Tänapäeval tundub ebatavalisena sinepiplaastri kasutamine sääremarjadel. Sellist kasutusviisi pakub aga 1877. aasta Eesti rahva mönnus Kalender esmaabiks - nii taimemürgistuse, ülespoodud ehk ärakägistud ehk mulla sisse vaibunud ehk äramagatud inimese puhul ning siis, kui keegi on äralämmatand auru, kaasi, söövingu ehk muu nendesar- 
naste asjade läbi (ERMK 1876: 50). Lisaks leiab sinepiplaaster olulist kasutamist peavalu ravis (PK 1879: 47; OK 1893: 23; UTT 1897: 97).

Malaariaravimina kasutatud kiniini isoleerisid prantsuse keemikud Pierre Joseph Pelletier ja Joseph Caventou 1820. aastal. Kiniini on esmakordselt mainitud 1880. aasta kalendris malaaria ravis pulbrina koos Wermuthiks ja Tresoliks nimetatud jookidega pruukides (PK 1879: 47), aastaid hiljem on kiniini soovitatud kasutada ka hambavalu puhul (ERKK 1886: 52). Möödaminnes on teda aga mainitud varemgi. 1857. aasta kalendris kirjutas Fr. R. Kreutzwald külmatõve ravist nõnda:

Aptegi peäl on kül sedda rohto, mis selle többe vasto on ja aitab; agga tallo rahvas ei sa iggakord sedda kätte, ja ei vötta ennast ka nenda hoida, kuida selle rohho prukimisse aial peab hoidma (MRK 1856).

Selle asemel soovitati talurahvale apteegist odavamat rohtu - ingverijuurt. Lisaks anti nõu valmistada ise koirohutinktuuri, kampripiiritust ja sisse võtta kriiti äädikaga (MRK 1856).

Esmakordselt ilmusid valuvaigistid kalendriravimite sekka 1893. aastal. Nendeks on oopiumitinktuur ja naatriumsalitsülaat. Oopiumitinktuuri on soovitatud hambavalu vastu (UTT 1897: 94; OK 1893: 20). Huvitav on mainida, et vahepeal "varjusurmas" olnud oopium võeti viimastel aastatel Euroopa farmakopöa ametliku preparaadina jälle kasutusele. Naatriumsalitsülaat on meditsiinis olnud kasutusel palavikku alandava ja reumavastase vahendina. Ainsa korrana on seda mainitud 1893. aasta kalendris reuma puhul (OK 1893: 20). Paraku on naatriumsalitsülaat kurikuulus oma seedetrakti ärritava ja iiveldust tekitava kõrvaltoime poolest, mistõttu leiab nüüdisajal kasutamist vaid välispidiseks otstarbeks.

Kreosoodi (pöökpuutõrvast destilleerimisel saadud fenoolide ja fenooleetrite segu; EF 1937) avastas Carl Reichenbach 1827. aastal. Ravimit on esmakordselt mainitud kalendriõpetustes hambavalu vastu 1881. aastal (IK 1880: 89). Selle desinfitseerivad omadused väärivad ka igati tunnustamist.

Antipüriin, sünteesitud 1884. aastal, jõudis kalendrisse üle kümne aasta hiljem merehaiguse ravimina (UTT 1897: 100). Tegelikult on ta teadusmeditsiinis kasutamist leidnud kui valuvaigistav, põletikuvastane ja palavikku alandav ravim.

Teistest ravimitest võiks nimetada veel jodoformi, mis sünteesiti 1882. aastal. Antiseptikumina tuntud jodoformsalvi soovitati kasutada esmakordselt 1893. aasta kalendris juhul, kui paise jookseb (OK 1893: 22) ning suure haava korral (UTT 1897: 99).

Mineraalvesi - selters - jõudis kalendriveergudele sajandi lõpupoole (IK 1879: 78; PK 1879: 47; ERKK 1886: 54). Seltersit ja teisi kunstliku mine- 
raalvee liike hakati Eesti apteekides valmistama juba 19. sajandi esimesel poolel. Esimene kunstliku mineraalvee aparaat paigaldati 1838. aastal Georg Heinrich Haetge apteeki Tallinnas ning samal ajal ka Haapsallu, kus samuti alustati seltersi tootmisega (Gustavson 1990: 31-33). Apteekides valmistati veel soodavett, mõru mineraalvett, sidrunilimonaadi jpm. Tähtraamatuis võib kohata aga järgmisi rohujooke: rammoto limonad (ERK 1856: 37), sitroni vesi (limonaad) (ERMK 1876: 56), mõruvesi (Bitterwasser) (OK 1893: 23), kremortartari vessi (ERK 1856: 37), kremortartari jok (ERK 1856: 37, 47), rabarberi rohho veddelus (ERK 1856: 37, 47), rinna tee (ERK 1857: 12), luksi vessi (ERK 1857: 19), higgi aiaja mikstura (ERK 1858: 40), raua-hapu-vesi (Fisenoridhydrat) (ERMK 1876: 55), lubja vesi (ERMK 1876: 55-56), kloorvesi (ERMK 1876: 55), magneesia vesi (ERMK 1876: 56), Dr. Liebreich'i Fichencacao (RTR 1886: 64), sinikivi vesi (IK 1879: 77), soda ehk kahekordse söehapu natroni vesi (KTRK 1885: 51), St. Germain thee (OK 1893: 20), kohv (ERMK 1876: 56; OK 1893: 21; UTT 1897: 94, 96), oksendamise vein (OK 1893: 22), sitroni sahvt (OK 1893: 21; UTT 1897: 94). Kanget kohvi soovitab kalender pruukida nii taime- kui ka seenemürgistuste korral seespidiselt (ERMK 1876: 56; OK 1893: 21; UTT 1897: 94), samuti klistiiri tegemiseks (ERMK 1876: 56), mis 19. sajandi lõpulgi polnud oma populaarsust minetanud.

\section{Toiduained ravimitena}

Toitumisele pööratakse kalendreis üksjagu tähelepanu. 1857. aasta kalendris ilmus koguni sellekohane artikkel "Ülleüldsed tähhelepannemissed toidusse prukimisses," mis on äärmiselt huvitav endisaegsete dietoloogiliste tõekspidamiste poolest. Siinjuures tuleb mainida, et 1857. aasta Eesti rahva Kalender on silmanähtavalt võõramaise päritoluga. Selles ilmunud koduapteegi taimedest tuleb juttu järgmises peatükis. Toitumissoovitustes kehtib mõõdukuse reegel (= Kange kassinusse ja lia sömisse vahhel on tarvis tähhele panna keskust), süüa soovitatakse kõike ja toidukordade osas piiranguid ei seata. Talurahvale näib kohatu avaldada mõtteid liigsöömisest ja selle vältimisest:

Issiärranis on tarvis ennast hoida keigesugguste kogide ja magguste eest, miskaga liggi ikka sured lounad löppevad; selle korra sees voib ennesele lubbaba nattikesse juusto, tas kohvi, veike klasi täis olgu mis taht maggusad ja mitte kanget selikest [---] (ERK 1856: 34) 


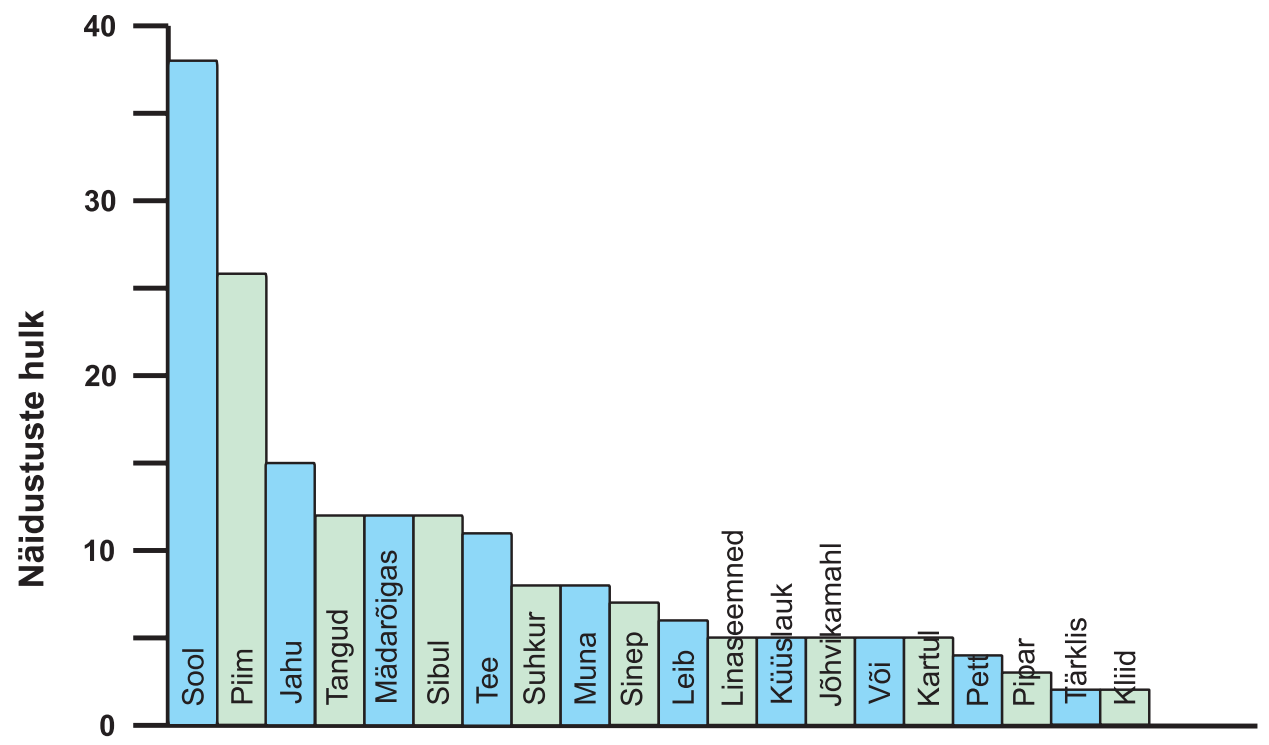

Joonis 3. Levinumad toiduained kalendriõpetustes.

ning lõuna juurde kuuluvast joogivalikust:

Vinade polest, mis voib jua pärrast sömist olgu parremaks reegliks se: et ühhesugguse vinaga rahul olla, näitusseks: Prantsusse vinadest - purgondi ja pordo vanna vinaga, poleks veega, ehk nenda kui ta on (ERK 1856: 35).

Kalendreis enim näidustatud toiduained on toodud joonisel 3. Korra on kõne alla tulnud riis (ERK 1857: 12), koor (EMRK 1805), kapsas (ERK 1882: 49), punapeet (SK 1895: 62), naeris (EMRK 1791).

Rahvameditsiinis laialt kasutamist leidnud sool on kalendriõpetusteski arvestataval kohal. Soola on mainitud peamiselt haavade ja paisete ravitsemisel (EMRK 1791; EMRK 1805; MRK 1823: 45; EMRK 1830; ERMK 1876: 54; EPMK 1878: 73; EMRK 1879: 59; KTRK 1879: 36, 37; PK 1879: 47; ERK 1882: 48; UTT 1897: 95). Muu hulgas on sool enim mainimist leidnud ka hambavalu puhul (IK 1880: 88-89; KTRK 1885: 51; KTRK 1891: 58; PMK 1895: 111; UTT 1897: 94-95), peamiselt ühe ravikomponendina. Nii on soola soovitatud tarvitada kombinatsioonis pipra, suhkru või sibulaga hamba sisse panemiseks, soola ja viina segust auru aga võiks sisse hingata. Samas on 1889. aasta Kasuline Talurahva Kalender teistsugusel seisukohal, väites, et sool on hammastele väga kahjulik, ehkki teda palju hambavalu juures pruugitakse (KTRK 1888: 57). Kanget soolvett kiidetakse heaks lutikaro- 
huks, mis mitte üksi lutikatele vastumeelt ei ole, vaid mis ka nende munad ära hävitab (ERPKK 1897: 38). Soovitus unetuse korral soolveega jalgu pesta (EK 1889: 123) ilmus rubriigis "Kasulikud teadused, mis vana rahvas on ära proovinud". Tuleb tõdeda, et külmade jalgade puhul võib soolveega pesemisest (kui vere liikumist soodustavast protseduurist) ka abi olla. Soolveega suu loputamine ja kurgu kuristamine on nüüdisajalgi igati tunnustatud raviviis, sest naatriumkloriid aitab põletikulist eksudaati kõrvaldada ja soodustab kudede paranemist.

Elustusvahenditena soovitatakse nina alla panna mädarõigast (EMRK 1792; EMRK 1803; EMRK 1804; EMRK 1830) ja rõigast (ERK 1863: 45) või küüslauku (EMRK 1803; EMRK 1804). Erandina on mädarõigast paaril korral samal otstarbel soovitatud ka kõrva taha asetada (EMRK 1792; EMRK 1804). Külgehakkava haigega kokku puutudes soovitatakse teha käed ja huuled kokku sibulamahlaga (OK 1893: 31). Küüslaugule ammusest ajast omistatud väge külgehakkavate haiguste (katk, koolera) vastu meenutatakse veel möödunud aegadestki (K 1892: 62; OK 1893: 31). Nii sibul kui ka küüslauk toimivad paljudele mikroobidele ja takistavad mitmete viirustegi elutegevust.

Kartulit kasutatakse eeskätt põletuste raviks (EMRK 1830; ERK 1858: 45; PK 1879: 47). Kartulist saavat leevendust ka öise hambavalu puhul, kui teda toorelt otsmikule asetada (PMK 1895: 111).

Tuleb ette sedagi, et söömine jääb haiguse ravimise või leevendamise ainukeseks soovituseks, näiteks tuulerõugete puhul:

Se többi saab issiennesest terveks, ühe lomusse väe läbbi. Temma arstimisseks on kül, et haige olleks koddu, vodis, sojas ja kuivas tuas, ja sööks ükspäinis neddelat [ilmselt trükiviga kalendris] suppi, ehk kedetud kalla leemi, agga mitte muud middagi (ERK 1857: 14).

\section{Taimsed ravimid}

Ravimtaimedest mainitakse kalendritekstides järgmisi: aedvaak (EMRK 1791), altee (ERK 1856: 37, 43), arnika (PERK 1879; PK 1879: 47), heinputk (ERK 1856: 40), humal (K 1870: 40), kadakas (EMRK 1791; EMRK 1792; TVMRK 1839: 51; PK 1879: 46), kalmus (ERK 1856: 40; PMK 1895: 111), kask (EMRK 1803; PERK 1879; K 1892: 62-64), koerapöörirohi (PERK 1879), koirohi (ERK 1856: 40; MRK 1856; PERK 1879), kummel (EMRK 1803; EMRK 1805; ERK 1856: 43-44; ERK 1857: 17; PERK 1879; ERKK 1886: 51-52; RTR 1886: 60-61; PMK 1895: 110), kurgirohi (ERK 1857: 14), kõrvits (EPMK 1874: 95), must leeder (MRK 1823: 42; ERK 1856: 40, 44; ERK 1857: 12, 19; ERK 
1858: 40; UTT 1897: 94), leeskputk (EMRK 1791), münt (MRK 1850: 28; ERK 1856: 37, 47; PERK 1879; K 1892: 63), nõges (ERK 1865: 43; UTT 1897: 95), paju (EMRK 1830), palderjan (ERK 1856: 45; ERK 1857: 19; ERKK 1886: 52), petersell (RTR 1886: 60), pohl (PMK 1895: 112), pärn (ERK 1856: 40, 45; ERK 1857: 12, 14, 17; ERK 1858: 40, 45; MRK 1863), raudrohi (EMRK 1803; TVMRK 1840: 51; ERK 1856: 44-45; PERK 1879), salvei (IK 1879: 78; PERK 1879), must sõstar (ERK 1856: 46; FGFT 1891: 58; ERPKK 1897: 44), tamm (EMRK 1830; ERMK 1876: 56; IK 1880: 89; KTRK 1880: 34; OK 1893: 21; UTT 1897: 94-95), tedremaran (ERK 1856: 45), teeleht (MRK 1823: 45; ERKK 1886: 52), vaarikas (ERK 1856: 40; ERK 1858: 40), vereurmarohi (ERK 1856: 37, 47; UTT 1897: 98). Lisaks eelnevatele taimedele käsitleb 1857. aasta Eesti rahva Kalender peatükis "Mönned sannad arstimisse taimette korristamissest ja kuivatamissest koddu-apteki tarvis" järgmisi taimi: aaskannike, ümaralehine kassinaeris, haisev kress, maajalg, maavits, mailane, orashein, punand, rihupeenlook ja ubaleht, mis on ühe kalendri piiresse paraku jäänudki.

Ülaltoodud nimistust on näha, et taimede loetelu polegi kuigi pikk. Enamasti piirdusid soovitused kummeli, musta sõstra, pärna, tamme ja raudrohuga - kõik tänapäevalgi väga tuntud ja kasutatud ravimtaimed. Kõige enam näidustatud taimed on toodud joonisel 4. Jooniselt on välja jäetud eelnimetatud kalendris koduapteeki kuuluvad taimed, sest tegemist oli ravimtaimedest käsiraamatulaadselt kirjutatud artikliga, mitte niivõrd õpetustega. Taimekirjelduste juurde kuulus hulk kõikvõimalikke näidustusi,

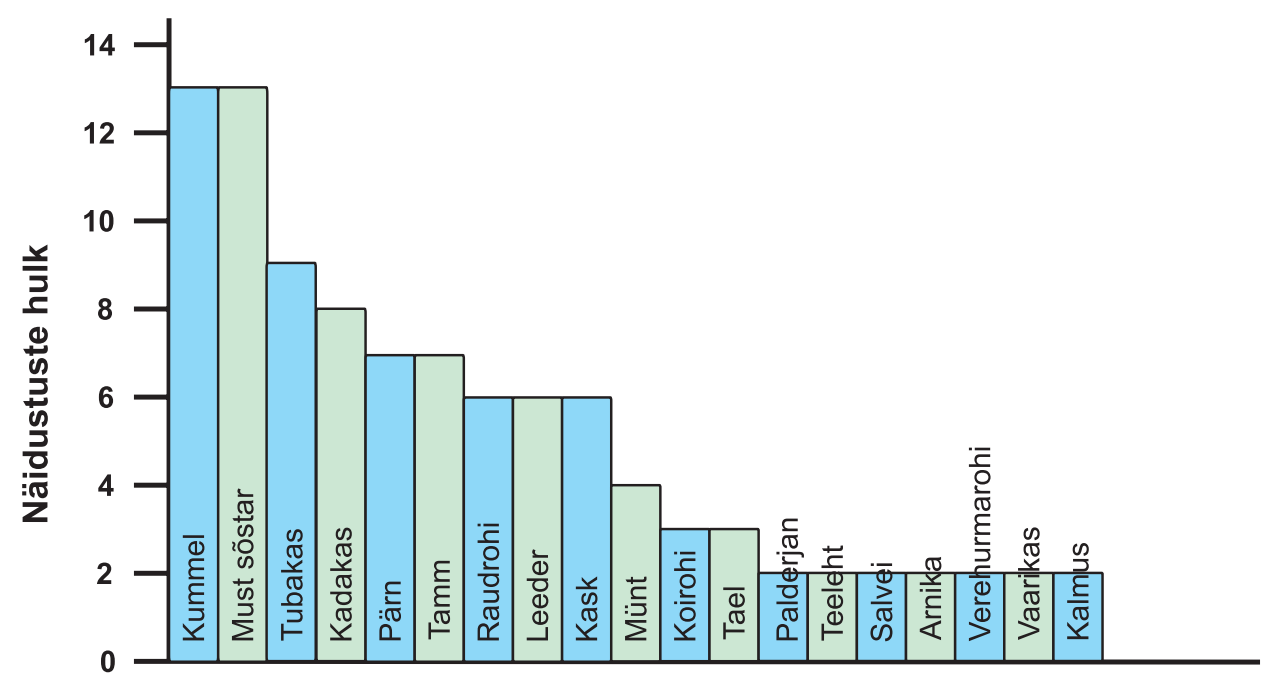
Joonis 4. Ravimtaimede nimetamise sagedus näidustuste hulga alusel (v.a koduapteegi taimed 1857. aasta Eesti rahva Kalendris). 
mille hulka arvesse võttes kaldunuks populaarsemate taimede sekka hoopis "tulnuktaimi", mida teistes kalendriõpetustes ei esine.

Enim näidustatud ravimtaimeks on kummel, mida kohtab kalendreis mitme nime all: kanna persed (EMRK 1803; ERK 1856: 43), übbina hain (ERK 1856: 43), kammel (ERK 1857: 17), kummel (PERK 1879; RTR 1886: 60), kummeli rohi (PERK 1879), kummelithee (RTR 1886: 61), kamelithee (PMK 1895: 110), kanalill (ERKK 1886: 51), kamel (PMK 1895: 110). Siinjuures jääb selgusetuks, kas kummeli all mõeldakse teekummelit (Chamomilla recutita) või lõhnavat kummelit (Chamomilla suaveolens). Sellesse ei too selgust ka Gustav Vilbaste Eesti taimenimetused (Vilbaste 1993), sest para$\mathrm{ku}$ on nii lõhnava kui ka teekummeli rahvapärased nimed suuremas osas ühtivad. Vaid paaril korral on kalendris soovitatud kasutada konkreetset taimeosa - kummeli õisikuid (ERK 1856: 43; PERK 1879; PMK 1895: 110). Teistel puhkudel on see mainimata jäetud. Kummeli näidustuste haare on väga lai. Omapäraseim näide pärineb 1896. aasta Põllumehe Kalendrist:

Kui jooksja haigus (Rheumatismus) hambavalul põhjuseks on, siis on tassike kamelitheed hea abinõuu; ühtlasi pandagu paar kameli õit kõrva.

Taimsete ravimite alla kuulub ka tael, mida soovitati kasutada verejooksu tõkestamiseks (EMRK 1791; EMRK 1805; PERK 1879) - seda kasutati tänapäevase plaastri funktsioonis.

Taimede kasutamise kohta jagab kalender väga erinevaid nõuandeid. Lisaks vesi- ja alkoholtõmmistele kohtab kahel korral õpetusi piimatõmmise (PERK 1879), ühel korral õli- (PERK 1879) ja äädikatõmmise (ERPKK 1897: 44) valmistamiseks. Taimetõmmistest on ligikaudne ülevaade antud joonisel 5. Vesitõmmise alla on liigitatud ka keedised, sest tekstides pole nendevahelised piirid väga selged ja põhirõhk on vee kui lahusti kasutamisel. Värske droogi all on silmas peetud ka taimest saadud mahla. Välja on jäetud eelmainitud 1857. aasta kalendri koduapteegi taimed.

Kõrvutades antud pilti rahvapärimusliku materjali põhjal läbi viidud uurimusega (Raal \& Pilve \& Pilve 1990: 72-76), on kalendrites nagu rahvameditsiiniski ülekaalukas vesitõmmiste osa. Märkimisväärne on ehk see, et alkoholtõmmistest rohkem on soovitatud kasutada värsket droogi. Alkoholina on nimetatud kõige enam viina (PERK 1879; FGFT 1891; ERPKK 1897) seejärel õlut (EMRK 1791; PERK 1879) ning ka piiritust (PERK 1879). Pulbristatud aineid on soovitatud kasutada kahel juhul: kadaka- ja loorberimarjapulbrit haavaplaastri valmistamiseks (EMRK 1791) ning seespidiselt sissevõtmiseks sügeliste ravis (TVMRK 1839: 51). 


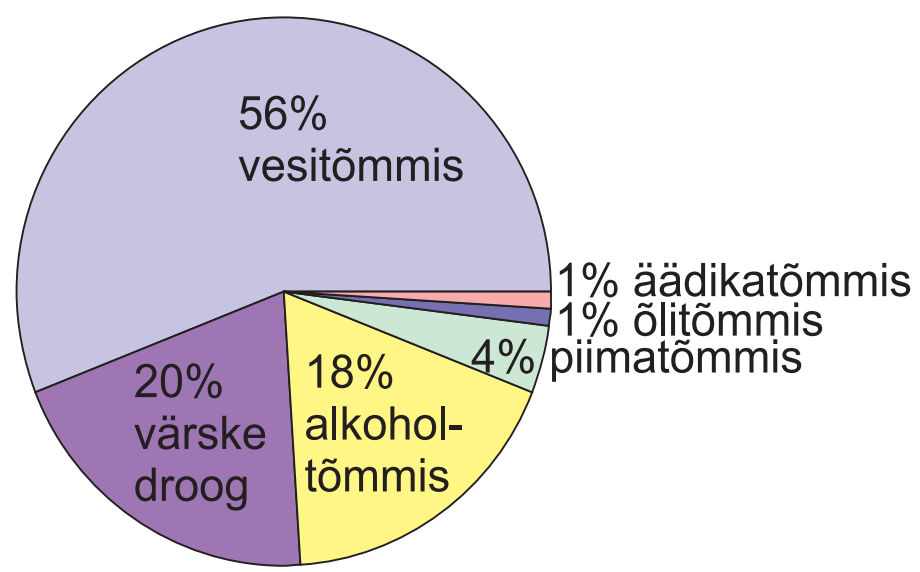

Joonis 5. Taimede võimalikke kasutusviise kalendriõpetustes.

\section{Vesi, äädikas ja alkohol}

Vesi, äädikas ja alkohol on 18. ja 19. sajandi kalendriravimite levinuimad ravivedelikud. Vee kasutamine ravimise juures on üleüldiselt levinud, olles ravimise lahutamatuks osaks. Elustamisvõtete puhul soovitati sageli kasutada vett lisaks teistele abinõudele. Levinud soovituseks oli vee pritsimine silmadele (EMRK 1804; 1830), tilgutamine südame piirkonda (EMRK 1803; EMRK 1804; EMRK 1830; PK 1879: 47) ning rinnale (EMRK 1803; 1830; ERMK 1876: 57; RTR 1886: 62-63). Väga populaarne on läbi aegade märgade mähiste kasutamine. 1898. aasta Isamaa Kalendris on avaldatud koguni artikkel "Veega arstimisest" dr. Sebastian Kneippi õpetustega, milles kõrgelt kiidetakse vee tervendavaid omadusi (IK 1897).

Äädikat on mainitud 20 kalendris ühtekokku 82 korral, see moodustab $7 \%$ kõigist ravimeist ja ravivõtetest. Äädikat soovitatakse peamiselt välispidiseks kasutamiseks (59 korral välispidine, 21 korral seespidine, 2 juhul nii sees- kui välispidine). Kalendriõpetustest järeldub, et äädikas on kõikeraviva toimega, peletades lutikaid (KTRK 1891: 58; KTRK 1893: 59), läkaköha (K 1892: 62), hambavalu (ERPKK 1897: 38), nakkushaigusi (EMRK 1798; PMK 1895: 110), sealhulgas ka katku jpm. Sageli nimetatakse äädikat elustamise juures, kus teda kasutatakse mitmel viisil: inhaleerimiseks (EMRK 1798; EMRK 1804; EMRK 1830; ERK 1858: 45; ERMK 1876: 51; IK 1879: 77; PK 1879: 46; OK 1893: 21; UTT 1897: 96), joomiseks (EMRK 1792; EMRK 1798; EMRK 1803; EMRK 1804; EMRK 1805; EMRK 1830; ERMK 1876: 56 57; IK 1879: 77; PK 1879: 47; UTT 1897: 94), välispidiselt, sh kompressiks (EMRK 1791; EMRK 1798; EMRK 1803; EMRK 1805; EMRK 1830; ERK 1857: 
17; ERK 1858: 45-46; ERMK 1876: 54; KTRK 1879: 37; PK 1879: 46; ERKK 1886: 54; KTRK 1893; ERPKK 1897: 38; UTT 1897: 93) ning klistiiriks (EMRK 1804; EMRK 1805; EMRK 1830). 18. sajandi lõpul levis arvamus, et nii külmunud inimesele kui ka külmumise vältimiseks tuleb juua anda äädikat (EMRK 1792; EMRK 1798). Profülaktilisel näidustusel soovitati lisaks äädikale süüa ka midagi soolast (EMRK 1792).

Alkohol leiab kalendris soovitusi eelkõige esmaabi korral (EMRK 1791; EMRK 1792; EMRK 1803; EMRK 1804; EMRK 1805; EMRK 1830; ERK 1857; ERK 1863; UTT 1897). Kõige enam on mainitud viina, mõnevõrra harvemini piiritust. Teistest alkohoolsetest jookidest on õpetustes ette tulnud punane vein (ERK 1857: 17; OK 1893: 21; UTT 1897: 94), vein (OK 1893: 20, 22; UTT 1897: 96), konjak (OK 1893: 20; UTT 1897: 94), rumm (IK 1880: 89; UTT 1897: 94) ning õlu (EMRK 1792; KTRK 1893: 55).

\section{Loomsed ravimid}

Loomse päritoluga ravimeid on tähtraamatutes käsitletud üllatavalt vähe. Proportsionaalselt jääb see umbes $2 \%$ piiresse kõigist ravimeist ja ravivõtetest. Kalendreis on enim mainimist leidnud rasv, sõnnik (sitt) ja mesi. Peamiselt kasutatakse loomseid ravimeid haavade ja põletuste ravis. Rasv ja meevaha on komponentideks haavaplaastrites (EMRK 1791). Põletatud kohale soovitatakse panna lehmasitta või konnakudu (EMRK 1805), samuti ämblikuvõrku (PK 1879: 47). Ussihammustuse puhul antakse nõu määrida haav kokku nõelanud ussi verega (UTT 1897: 94). Rasva kui väga käepärast vahendit on välispidiselt soovitatud põletuse (ERMK 1876: 54), roosi (ERK 1858: 39), luuvalu (PK 1879: 47), nikastuse (EMRK 1805) jm puhul. Läbi sajandite pole kadunud külmumisest hoidumise juures ka õpetus keha määrimisest rasvaga (EMRK 1791; EMRK 1792; ERK 1863: 47).

1792. aasta Eesti Ma-Rahva Kalender soovitab paisete lahtikiskumiseks kasutada saastast Villa, mis Lamba kubbemette vahhel, ja Rotti-sitta meega. Looma väljaheidetega arstimine kannab endas keskaegse meditsiini põhimõtteid, mis olid visad rahvameditsiinist kaduma. Rooja tarvitamine oli pikka aega populaarne, seda mitte ainult rahvameditsiinis, vaid ka endisaegses teaduslikus meditsiinis. Näiteks avaldati Saksamaal veel 1792. aastalgi arstiteaduslik raamat Neue vermehrte heylsame Dreck-Apotheke, wie nemlich mit Kot und Urin fast alle ja auch die schwersten Krankheiten curieret werden (Uus täiendatud tervistav mustuse-apteek, mis sellesama rooja ja uriiniga peaaegu kõigist ja kõige raskemaistki haigustest terveks teeb). Uriiniravi propageerivat kirjandust on näiteks vene keeles tõsimeeli välja antud nüüdisajalgi. 
Ilmari Mannineni seletuste kohaselt arvanud maarahvas, et mustuse abil on võimalik haigust ära kolima sundida (Manninen 1925: 458). Kalendreis kohtame roojaga ravitsemise õpetusi 19. sajandi lõpuski, mil lugejale tutvustati üht eksootilist ravitsemisvahendit - kaamelisõnnikut - mida Taga-Kaspia tatarlased edukalt hambavalu puhul kuivatatult piibus suitsetasid. Säärase abinõu kohta on öeldud, et võtab kindlasti jäädavalt valu ära, nõnda et hambad küll võivad suus ära pudeneda, aga iialgi valu ei tee (KTRK 1891: $58)$.

Loomasõnnikut on soovitatud vaid välispidiseks kasutamiseks ning see tuleb kalendreis kõne alla peamiselt esmaabi puhul (EMRK 1792; EMRK 1803; EMRK 1805; ERK 1863: 47), ehkki rahvameditsiinis on roojaravimid (rotisitt, lehmasõnnik) olnud kasutusel näiteks roosi ja silmahaiguste ravis (Veidemann 1985: 144). Uppunu elustamise juures on sõnnik (sitt) soojendava vahendina üheks paljudest võimalikest abinõudest (EMRK 1792; EMRK 1803). Sooja kanasõnniku kohta mainitakse, et Rootsis kasutatavat seda külmumise tagajärjel tuimade ja paistetanud jäsemete määrimiseks (ERK 1863: 47).

\section{Segurohud ja teised ravimid}

Nn segurohud moodustasid väikese osa kõigist ravimeist. Nende poolest silmapaistev on 1792. aasta Eesti-Ma Rahva Kalender, kus õpetatakse haavade ravitsemiseks valmistama ühtekokku 11 erinevat plaastrit. Plaastri komponentidena on nimetatud meevaha, küünlarasva, hanerasva, männivaiku, munarebu, juudasitta, loorberi- ja kadakamarju, linaõli, mett, seepi, õlut jm. Omapärase retsepti annab haavade raviks 1880. aasta Pärnu Eestirahva Kalender, kus õpetatakse valmistama rohelist plaastrit. Selleks tuleb kange õllega keeta raudrohuõisi ja -lehti ning sellele lisada kitse- või lambarasva, meevaha ja vaiku.

Teiste ravimite seas võib mainida mulda. Külma mulda on soovitatud panna mesilase nõelatud kohale (IK 1879: 77; RTR 1886: 60). Pikselöögi tabamuse korral soovitatakse kannatanu aga mullaga katta ja tilgutada talle pähe külma vett (EMRK 1804; UTT 1897: 96).

Süsi leiab õpetustes rakendust haavade ravis (K 1870: 41; PERK 1879; KTRK 1893: 57; UTT 1897: 94, 100), ajaleht liigniiskete jalgade ümber mässimiseks (UTT 1897: 97), paber nahakriimustuse korral süljega pealepanemiseks (PMK 1895: 110), hall paber äädika sisse kastetult haavast verejooksu peatamiseks (EMRK 1805), kusi haava pesemiseks (EMRK 1791; EMRK 1805; 1830; ERMK 1876: 54; EMRK 1879: 59), küünlarasv nohu korral põske- 
dele määrimiseks (PK 1879: 47), tint põletustele (EMRK 1830; ERK 1858: 45), seep lahtiste juuste korral pea pesemiseks (KTRK 1888: 60; OK 1893: 20; UTT 1897: 96), kõhukinnisuse puhul klistiiri tegemiseks (RTR 1886: 62), lahusena mürgistuse korral joomiseks (EMRK 1830; ERMK 1876: 55; OK 1893: 21; UTT 1897: 94) ning marutõbise koera hammustusest saadud haava pesemiseks (EMRK 1830; ERMK 1876: 54; EMRK 1879: 59). Tuhka aga võib panna sooja vee sisse, kuhu kägistatud või poodud inimene elustamiseks põlvini sisse asetatakse (EMRK 1803).

\section{Kokkuvõtteks}

Meditsiiniliste õpetuste osa kalendrites on aegade jooksul muutunud - esimestes kalendrites moodustas see kogu kalendrilisa mahu, hiljem muutus aga üheks jutuks paljude seas. 19. sajandi lõpupoole kahanesid õpetused aga nõuanneterubriigi lõikudeks. Kalendrites avaldatud meditsiinialased kirjutised polnud olemuselt kaugeltki homogeensed, vaid kandsid endas nii rahvameditsiini kui ka teadusmeditsiini tõekspidamisi. Viimased olid ülekaalus, millest annab tunnistust apteegirohtude sagedasem nimetamine võrreldes teiste ravimitega ning kalendrite tauniv suhtumine ebaratsionaalsesse rahvapärasesse ravitsemisse. Rahvameditsiini ravipõhimõtted - sarnasega sarnase ravi; ravimi päritolu olgu sealt, kust haiguski ning rohi olgu kangem kui haigus - kalendrites selgelt ei avaldu. Maagilistest ravimitest kalendrid üldjuhul hoiduvad, erandiks on roosi ravimine, mille korral on mainitud rahvapäraseid maagiliste sugemetega ravimeid. Kalendrid olid oma ajast nii taga kui ka ees - laiemalt võttes jõudis meditsiiniline teave kalendritesse hilinemisega. Oma aja teaduslike saavutuste seisukohalt jõudsid need kalendritesse viivitustega, samas kui maarahva seisukohalt vaadatuna oli kirjutatu oma ajast pigem ees. Seda peegeldavad mõnedki õpetused, mis olemuselt ja sisult on avaldatud võõras kontekstis, hetkeseisu arvestamata.

Ravimikasutus muutub sajandi lõikes märgatavalt vaid apteegirohtude osas. Nende osa kasvas oluliselt 19. sajandi teisel poolel, samas kui toiduainete, taimsete ja loomsete ravimite puhul pole erinevused märkimisväärsed.

Teema jätkuks oleks vajalik kalendrimeditsiini ja rahvameditsiini pärimusliku materjali omavaheliste korrelatsioonide analüüs. See võimaldaks hinnata kalendrite mõju maarahva meditsiinilisele mõtlemisele ja teadmistele: kas ja kuivõrd mõjutas kalendrimeditsiin rahvameditsiini, mida ja kui palju võttis maarahvas kalendriõpetustest üle, mida tõlgendati omamoodi 
või mugandati. Samme on sellel teel astunud Renata Sõukand, uurides kahe võõramaist päritolu taime positsiooni rahvameditsiini ja 19. sajandi meditsiinikirjanduse (sh kalendrikirjanduse) valguses (Sõukand 2007) ja Raivo Kalle oma uurimusega eesti taimestikku naturaliseerunud ravimtaimeliikidest (Kalle 2007). Kalendrikirjanduse mõju ilmnemine rahvameditsiinis annab omakorda hea võrdlusmaterjali uurimaks tänapäevase populaarmeditsiinilise kirjanduse rolli inimeste meditsiinialaste teadmiste kujunemisel.

\section{Kommentaar}

${ }^{1}$ Autori tänu kõigile, kes olid abiks artikli valmimisel, eriti aga Renata Sõukandile ja Ain Raalile, kelle abiga kujunes samateemaline diplomitöö käesolevaks artikliks.

\section{Kirjandus}

Alatalu, Riin 1992. Meditsiinilise mõtte areng Eestis 19. sajandil eestikeelse kalendrikirjanduse näitel. Diplomitöö. Käsikiri Tartu Ülikooli eesti ajaloo õppetoolis.. Tartu: Tartu Ülikool.

Annus, Endel 1975. Eesti kalendrikirjanduse ajalugu kuni $1860=$ Нстория эстонской календарной митературы до 1860 в. 1. Kandidaadidissertatsioon. Tartu: Tartu Riiklik Ülikool, eesti kirjanduse ja rahvaluule kateeder.

Annus, Endel (toim) 1995a. Eestikeelne raamat 1851-1900 = Estnisches Buch, 18511900 1: A-Q. Eesti retrospektiivne rahvusbibliograafia $1=$ Estnische retrospektive Nationalbibliographie 1 = Estonian retrospective national bibliography $1=$ Эстонская ретроспективная национальная библиография 1. Tallinn: Eesti Teaduste Akadeemia Raamatukogu.

Annus, Endel (toim) 1995b. Eestikeelne raamat 1851-1900 = Estnisches Buch, 18511900 2: R-Y. Eesti retrospektiivne rahvusbibliograafia 1 = Estnische retrospektive Nationalbibliographie 1 = Estonian retrospective national bibliography $1=$ Эстонская ретроспективная национальная библиография 1. Tallinn:Teaduste Akadeemia Raamatukogu.

Annus, Endel (toim) 2000a. Eestikeelne raamat 1525-1850 = Estnisches Buch 15251850 = Estonian book 1525-1850. Eesti retrospektiivne rahvusbibliograafia I = Estnische retrospektive Nationalbibliographie I = Estonian retrospective national bibliography I. Tallinn: Eesti Akadeemiline Raamatukogu.

Annus, Endel 2000b. Eesti kalendrikirjandus 1720-1900. Tallinn: Teaduste Akadeemia Kirjastus.

Arvelius, Friedrich Gustav (koost). 1790. Ramma Josepi Hädda-ja Abbi-Ramat: Ehk maggusad ja tullusad juttud ja öppetussed, kuida ma-rahvas voib röömsaste ellada, ausal visil rikkaks sada, ja isse ennesele ja mu rahvale monnesugguses häddas ja viletsusses abbi tehha. Tallinn. 
Baer, Karl Ernst von 1976 [1814]. Eestlaste endeemilistest haigustest. Loomingu Raamatukogu 33 (977). Tallinn: Perioodika.

EF 1937 = Eesti farmakopöa: Esimene väljaanne = Pharmacopoea Estonica: Editio prima. Tallinn: Sotsiaalministeeriumi Farmaatsia Inspektuur.

Gustavson, Heino 1990. Toiduainete tootmisest Eesti apteekides 19. saj. - 1914. a. Arak, Elmar (toim). Eesti Farmaatsia III kongressi materjalid. Tartu: Tartu Ülikool, lk 3134 .

Jannau, Otto August von 1857. Ma-rahva Koddo-Arst, ehk, lühhikenne juhhataja, kuida iggaüks mõistlik innimenne ommas maias ja perres, kui kegi haigeks saab, agga arsti ep olle sada, vöib aidata. Tartu: H. Laakmann.

Kalle, Raivo 2007. Naturaliseerunud ravimtaimed etnobotaanika vaatenurgast. Hariliku katkujuure, hariliku siguri, aedvaagi, aed-mädarõika, hariliku seebilille ja lõhnava kannikese näitel. Mäetagused: Hüperajakiri 36, lk 105-128 (vt ka http:// www.folklore.ee/tagused/nr36/kalle.pdf).

Kangur, Gerli 2004. Eesti raamatukaupmehed raamatute reklaamijatena 19. sajandi teisel poolel. Kiipus, Merike (koost). Paar sammukest XXI: Eesti Kirjandusmuuseumi aastaraamat 2004. Tartu: Eesti Kirjandusmuuseum, lk 89-100.

Loosme, Ingrid 1966. 1860-1870-ndate aastate juturaamat ja selle lugeja. Siimisker, Helene (koost). Paar sammukest eesti kirjanduse uurimise teed: Uurimusi ja materjale IV. Tartu: Eesti NSV Teaduste Akadeemia, lk 58-100

Manninen, Ilmari 1925. Üldjooni meie rahvameditsiinist. Eesti Kirjandus 11, lk 453459.

Nirk, Endel 1968. Kreutzwald ja eesti rahvusliku kirjanduse algus. Tallinn: Eesti Raamat.

Noodla, Kaja 1986. Eesti raamatu lugeja XVIII sajandi lõpul ja XIX sajandi algul. Olesk, Sirje \& Veidemann, Rein (toim). Paar sammukest Eesti kirjanduse uurimise teed XI. Tallinn: Eesti Raamat, lk 8-30.

Raal, Ain \& Pilve, Enn \& Pilve, Helle 1990. Ravimtaimede kasutamisest Eesti rahvameditsiinis. Eesti Farmaatsia III kongressi materjalid. Tartu: Tartu Ülikool, lk 72-76.

Sõukand, Renata 2007. Kuidas võõras muutub omaks: kaks taime eesti rahvameditsiinis. Mäetagused: Hüperajakiri 36, lk 79-104 (vt ka http://www.folklore.ee/tagused/ nr36/soukand.pdf).

Talve, Ilmar 2004. Eesti kultuurilugu: Keskaja algusest Eesti iseseisvuseni. Tartu: Ilmamaa.

Wallner, Rudolf (= Vallner, Rudolf) 1929. Eesti rahvarohtude sõnastik: Käsiraamat apteekritele ja arstidele. Tallinn: R. Wallner.

Veidemann, Andra 1985. Rahvapärased arusaamad roosihaigusest ja selle ravimisest Eestis 19. sajandil ja 20. sajandi algul. Viires, Ants (toim). Eesti külaelu arengujooni. Tallinn: Eesti NSV Teaduste Akadeemia, lk 130-148

Viires, Ants 1992. Eesti talurahva ajalugu 1. Tallinn: Olion.

Vilbaste, Gustav 1993. Eesti taimenimetused = Nomina vernacula plantarum Estoniae . Eesti Teaduste Akadeemia Emakeele Seltsi toimetised 20p Tallinn: ETA Emakeele Selts (http://www.loodus.ee/vilbaste/ - 15. jaanuar 2007). 
Vinkel, Aarne (toim) 1965. Eesti kirjanduse ajalugu: viies köites 1: Esimestest algetest XIX sajandi 40-ndate aastateni. Tallinn: Eesti Raamat.

Wilde, Peter Ernst 1771. Arsti raamat nende juhhatamisseks kes tahtvad többed ärraarvada ning parrandada. Hupel, August Wilhelm (tõlk). Põltsamaa: W. J. v. Lauw.

\section{Kalendrid}

EK 1889 = Eesti Kalender 1890 aasta peale. Tallinn: H. Mathiesen.

EK 1892 = Eesti Kalender 1893 aasta peale. Tallinn: H. Mathiesen.

EMRK 1791 = Eesti-Ma Rahva Kalender, ehk Täht-Ramat 1792. Aasta peäle, pärrast meie Issanda Jesusse Kristusse Sündimist. Tallinn: Lindfors.

EMRK 1792 = Eesti-Ma Rahva Kalender, ehk Täht-Ramat 1793. Aasta peäle, pärrast meie Issanda Jesusse Kristusse Sündimist. Tallinn: Lindfors.

EMRK 1798 = Eesti-Ma-Rahva Kalender, ehk Täht-Ramat 1799. Aasta peäle, pärrast meie Issanda Jesusse Kristusse Sündimist. Tallinn: Lindfors.

EMRK 1803 = Eesti-Ma-Rahva Kalender, ehk Täht-Ramat 1804 Aasta peäle, pärrast meie Issanda Jesusse Kristusse Sündimist. Tallinn: Minuth.

EMRK 1804 = Eesti-Ma-Rahva Kalender, ehk Täht-Ramat 1805 Aasta peäle, pärrast meie Issanda Jesusse Kristusse Sündimist. Tallinn: Minuth.

EMRK 1805 = Eesti-Ma-Rahva Kalender, ehk Täht-Ramat 1806 Aasta peäle, pärrast meie Issanda Jesusse Kristusse Sündimist. Tallinn: Minuth.

EMRK 1830 = Knüpffer, Arnold Friedrich (toim). Eesti-Ma Rahva Kalender, ehk TähtRamat 1831 Aasta peäle, pärrast meie Issanda Jesusse Kristusse sündimist. Tallinn: J. H. Gressel.

EMRK 1879 = Kivi, H. (koost). Eesti-maa-rahva Kalender ehk Täht Raamat 1880 aasta peale pärast meie Issanda Jeesuse Kristuse sündimist. Tallinn: Lindforsi pärijad.

EPMK 1874 = Jannsen, Johann Voldemar (koost). Eesti Postimehe Kalender ehk aastaraamat 1875 aasta pääle. Tartu: H. Laakmann.

EPMK 1878 = Jannsen, Harry (koost). Eesti Postimehe Kalender ehk aasta-raamat 1879 aasta pääle. Tartu: H. Laakmann.

ERK 1856 = Eesti rahva Kalender se 1857 aasta peale pärrast J. Kristusse sündimist: Se Kalender on Öigeussu tunnistusse rahwa tarbeks sisseseädetud. Riia: Müller.

ERK 1857 = Eesti rahva Kalender se 1858 aasta peale pärrast J. Kristusse sündimist: Se Kalender on Öigeussu tunnistusse rahwa tarbeks sisseseädetud. Riia: Hartung.

ERK 1858 = Eesti rahva Kalender se 1859 aasta peale pärrast J. Kristusse sündimist; Se Kalender on Öigeussu tunnistusse rahva tarbeks sisseseädetud. Riia: Hartung.

ERK 1863 = Eesti rahva Kalender se 1864 aasta peale pärast Jesuse Kristuse sündimist: Se Kalender on Öigeussu tunnistusse rahva tarbeks sisseseädetud. Riia: Ernst Plates.

ERK 1865 = Eesti rahva Kalender se 1866 aasta peale pärast J. Kristuse sündimist: Se Kalender on Öigeussu tunnistusse rahva tarbeks sisseseädetud. Riia: Ernst Plates. 
ERK 1882 = Bruhns Emil Johann Heinrich (koost). Eesti Rahva Kalender ehk Täht raamat 1883 aasta peale pärast meie Issanda Jeesuse Kristuse sündimist. Tallinn: Eestimaa sinod.

ERKK 1886 = Eesti-rahva Kasuline Kalender 1887. aasta peale. Tartu: H. Laakmann. ERMK 1876 = Eesti rahva mönnus Kalender ehk Täht-Ramat 1877 aasta peäle, pärrast Issanda Jesusse Kristusse sündimist. Kuressaare: Ch. Assafrey.

ERPKK 1897 = Eestirahva Perekonna kalender 1898. Jurjev (= Tartu): J. Ungerson.

FGFT $1891=$ F. G. Faure 1892. aasta kingituse Tähtraamat $:$ Tartu apteegi-, rohu ja värvi kauplus. Tartu: F. G. Faure.

IK 1879 = Isamaa Kalender 1880 aasta peale. Tartu: Schnakenburg.

IK 1880 = Isamaa Kalender 1881 Piltidega . Tartu: Schnakenburg.

IK 1889 = Isamaa Kalender 1990 aasta peale. Tartu: Schnakenburg.

IK 1897 = Isamaa Kalender 1898 aastaks. Tartu: Schnakenburg.

K 1870 = Kalender ehk Täht-Ramat 1871 aasta peäle pärrast Kristusse sündimist . Kuressaare: Ch. Assafrey.

K 1892 = Mihkelson, P. (koost). Kalender ehk Täht-Raamat 1893 aasta peale, millel 365 pääva on: Õigeusuliste Eestlaste kasuks. Riia: M. Jakobson.

KTRK 1879 = Kasuline Talurahva Kalender 1880. Tartu: Schnakenburg.

KTRK 1880 = Kasuline Talurahva Kalender 1881. Tartu: Schnakenburg.

KTRK 1885 = Kasuline Talurahva Kalender 1886. Tartu. Schnakenburg.

KTRK 1888 = Kasuline Talurahva Kalender 1889. Tartu: Schnakenburg.

KTRK 1891 = Kasuline Talurahva Kalender 1892. Tartu: Schnakenburg.

KTRK 1893 = Kasuline Talurahva Kalender 1894. Tartu: Schnakenburg.

MRK 1823 = Masing, Otto Wilhelm (toim). Marahva Kalender ehk Täht-ramat 1824 aasta peäle, pärrast Jesuse Kristuse sündimist, tehtud. Perno (= Pärnu): O. W. Masing.

MRK 1850 = Reinthal, Carl Gottlieb (toim). Ma-rahva Kalender ehk Täht-ramat 1851 Ajjastaja päle, pärran Issanda Jesuse Kristuse sündimist. Tartu: J. C. Schünmanni lesk \& C. Mattiesen.

MRK 1856 = Ma-rahva Kalender ehk Täht-ramat 1857 aasta peäle, pärrast Jesusse Kristusse sündimist. Pärnu: W. Borm.

MRK 1863 = Ma-rahva Kalender ehk Täht-ramat 1864 aasta peale, pärrast Jesusse Kristusse sündimist. Pärnu: W. Borm.

OK 1893 = Oleviku Kalender 1893 aasta tarvis. Jurjew (= Tartu): A. Grenzstein.

PERK 1879 = Otstavel, Jaan (toim). Pärnu Eesti-rahva Kalender ehk Täht-raamat 1880 aasta pääle, pärast Jeesuse Kristuse sündimist. Pärnus: W. Borm.

PK 1879 = Pärnu Kalender ehk Täht-raamat 1880 aasta pääle, pärast Jeesuse Kristuse sündimist. Tartu: G. V. Rosenberg.

PMK 1895 = Põllumehe Kalender 1896 aastaks. Tartu: Hendrik Laas.

RTR 1886 = Tõnisson, Mats. Rahva Täht-raamat (Adressi kalender) 1887 aasta jaoks, millel 365 päeva on. Vändra: M. Tõnisson. 
SK 1895 = Saarlaste Kalender ehk Täht-Raamat 1896 aasta pääle. Kuressaare: Kuresaare nädalaleht.

SL 1898 = Sirvilauad 1899: Eesti rahva Tähtraamat 1899 aasta jaoks. Jurjev (= Tartu): Eesti Üliõpilaste Selts.

TVMRK 1839 = Tarto- ja Võrro-ma rahva Kalender ehk Täht-ramat 1840 Ajastaja päle, perran Issanda Jesusse Kristusse sündimist. Tartu: Liivimaa Üldkasulik ja Majanduslik Selts.

TVMRK 1840: Tarto- ja Võrro-ma rahva Kalender ehk Täht-ramat 1841 Ajastaja päle, perran Issanda Jesusse Kristusse sündimist. Tartu: Liivimaa Üldkasulik ja Majanduslik Selts.

UTT 1897 = Uus Taaralaste Tähtraamat 1898 aasta peale. Tallinn: R. Schiffer \& H. Tiedermann.

\section{Summary}

\section{Medicine in the 18th- and 19th-century Estonian almanacs}

\section{Stella Martsoo}

Key words: remedies, Estonian calendar literature, almanacs, medicine, drugs and medicines, curing, 18th and 19th century

How could "pharmaceuticals" like elecampane root, asaphoetida resin, nitric, etc. be used as remedies in folk medicine? One route was the local manor lords and their wives, who disseminated the knowledge they had acquired both from the literature published in Germany as well as from personal experimentation. Another weighty source may have been the late 18th-century almanacs that were published in the Estonian language and the popular medical literature, the publication of which escalated in the late 19th century and which introduced recent news on medicine. The almanacs were the first literary sources for peasants to acquire medical wisdom from. Since their popularity, the almanacs had a profound influence on the population. This paper discusses the advices on medicines and treatment published in medical texts in the almanacs of the period. Since drugs used for treatment were not medicines in the contemporary sense of the word, the term "medicament" should be defined more generally.

The most common food products used as remedies were salt, milk, and meal. A subtopic of the paper concerns various herbs, whereas a closer look is taken at herbs for home remedy and the possible usages. The most common herbs were camomile, blackcurrant and tobacco. Another subtopic discusses major drugs - water, vinegar and alcohol. The third subtopic explores the bestial remedies in calendar medicine, the most popular of which were fat, dung, and honey. 